\title{
Impact of information and communication technology in Nigerian small-to medium-sized enterprises
}

\author{
Kessington Okundaye \\ Rekun Technologies, Pasadena, California, USA, and \\ Susan K. Fan and Rocky J. Dwyer \\ College of Management and Technology, Walden University, Minneapolis, \\ Minnesota, USA
}

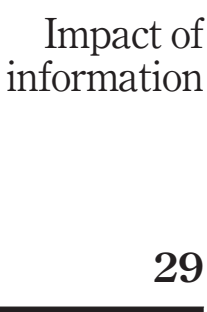

Received 29 August 2018 Revised 18 October 2018 Accepted 22 October 2018

\begin{abstract}
Purpose - The purpose of this (qualitative, multiple-case) study is to determine how small-to medium-sized enterprise (SME) leaders in Nigeria use information and communication technology (ICT) adoption as a business strategy to increase profitability and compete globally.

Design/methodology/approach - The participants for this study consisted of executive-level SME leaders who had the authority to approve ICT implementation within their respective organizations. Individual interviews were undertaken with participants to gain an understanding of their experience of determining the merits of and implementing ICT. The technology acceptance model, which specifies the relationship between perceived usefulness, perceived ease of use, attitude toward computer use and intention to use technology, was applied as a framework to explain the Nigerian SME's ICT adoption strategies.

Findings - Four major themes emerged from the data analysis: ICT adoption factors, ICT roles and benefits, role of government and SME success factors. The findings of this study may help SME leaders and government leaders address many of the factors inhibiting the adoption of ICT in SMEs in Nigeria.

Practical implications - This study may ensure that SMEs are successful and able to create jobs, which in turn may help to promote socioeconomic development through adoption of ICT.

Originality/value - The findings from this study contribute to the knowledge base regarding factors that affect ICT adoption by SME leaders as a business strategy to increase profitability and compete globally, particularly within SMEs in Lagos, Nigeria. It further addressed the gap in existing literature regarding other factors such as the influence of culture on ICT adoption, cost of ICT implementation, available ICT skills, infrastructure and ICT knowledge gap as the primary impeding factors of ICT adoption in Nigerian SMEs.
\end{abstract}

Keywords Innovation, Business growth, ICT adoption rates, ICT penetration, Information and communication technology adaptation

Paper type Research paper

(C) Kessington Okundaye, Susan K. Fan and Rocky J. Dwyer. Published in Journal of Economics, Finance and Administrative Science. Published by Emerald Publishing Limited. This article is published under the Creative Commons Attribution (CC BY 4.0) licence. Anyone may reproduce, distribute, translate and create derivative works of this article (for both commercial and noncommercial purposes), subject to full attribution to the original publication and authors. The full terms of this licence may be seen at http://creativecommons.org/licenses/by/4.0/legalcode
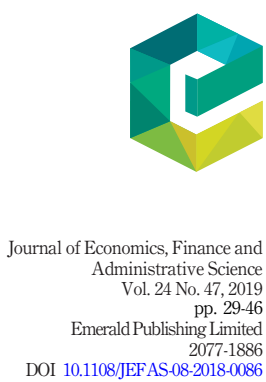
JEFAS

24,47

\section{Introduction}

The implementation of information and communication technology (ICT) in small-to medium-sized enterprises (SMEs) is vital for the socioeconomic development of an economy, especially in developing countries (Rahayu and Day, 2017; Yunis et al., 2017). Leaders of SMEs incrementally use ICT-based electronic commerce to gain competitive advantage in the global marketplace (Rahayu and Day, 2017; Tob-Ogu et al., 2018; Zafar and Mustafa, 2017). Despite the growth of ICT-based electronic commerce within SMEs in developed countries, the rate of ICT adoption within SMEs in developing countries has remained relatively low (Napitupulu et al., 2018; Rahayu and Day, 2017). The low adoption rate of ICT by SME leaders in developing countries such as Nigeria has contributed to a low rate of economic development in these countries (Jones et al., 2014; Rahayu and Day, 2017; Tob-Ogu et al., 2018; Zafar and Mustafa, 2017).

SMEs are an integral part of innovation and growth in a dynamic economy; thus, SMEs have a vital role in job creation (Napitupulu et al.,2018; Niebel, 2018; Zafar and Mustafa, 2017). In developed countries, such as the USA and United Kingdom, SMEs account for over 99 per cent of employers and contribute over 50 per cent to the country's gross domestic product (GDP); (Gbandi and Amissah, 2014; Tobora, 2014). In developing countries, such as Ghana, SMEs contribute approximately 70 per cent to the GDP and account for approximately 92 per cent of business (Zafar and Mustafa, 2017). In Nigeria, SMEs conduct 90 per cent of business in the country but contribute less than 10 per cent to the GDP (Gbandi and Amissah, 2014).

Growth in ICT adoption within both large and small businesses in developed countries had been significant (Niebel, 2018; Rahayu and Day, 2017). However, the ICT adoption rate within SMEs in developing countries has remained relatively low (Yunis et al., 2017; Rahayu and Day, 2017). Innovation in ICT has contributed to the improvement of organizational performance and the achievement of competitive advantage for organizations within developed and developing countries (Niebel, 2018). Global competitiveness and the need to stimulate growth are compelling reasons why leaders of SMEs need to adopt ICT (Niebel, 2018; Rahayu and Day, 2017; Yunis et al., 2017).

\section{Lower information and communication technology - a problem in developing countries}

In developing countries, SMEs have lower ICT adoption rates and different challenges compared to their counterparts in developed countries (Niebel, 2018; Rahayu and Day, 2017; Yunis et al., 2017; Zafar and Mustafa, 2017). The difference between ICT penetration rates in developing and developed countries is substantial, as developed countries have a significantly higher internet penetration rate of 78.3 per cent compared to 32.4 per cent for developing countries (International Telecommunication Union [ITU], 2014). Likewise, the percentage of households with computers in developed countries was 75.5 per cent, compared to 27.6 per cent for developing countries (ITU, 2014).

\section{Research thrust}

The central research question explored by this paper was as follows: How do SME leaders in Nigeria use ICT adoption as a business strategy to increase profitability and compete globally?

\section{Method and limitations}

This paper used a qualitative research method which involved collecting and analyzing qualitative narrative data from randomly selected business owners registered as community 
partners with the Small and Medium Enterprises Development Agency of Nigeria. Within each of four SMEs, five senior leaders with extensive expertise in the subject area and who had participated in ICT adoption decisions within their respective organizations were interviewed. The paper relied on the participants' interpretation regarding the impact of ICT adoption within each of the respective SMEs.

\section{Conceptually}

In this study, the technology acceptance model (TAM) was applied as a framework to explain the ICT adoption strategies of SME leaders in Nigeria. The TAM specifies the relationship between perceived usefulness, perceived ease of use, attitude toward computer use, and intention to use technology (Wunnava, 2015; Yeh, 2015). The TAM is an established theoretical model used to explain and predict user behavior toward ICT, where perceived usefulness is one of two causal antecedents of adoption and use of new technology (Abdullah and Ward, 2016; Rahayu and Day, 2017; Toft et al., 2014). The TAM is the most significant extension of Ajzen and Fishbein's theory of reasoned action (TRA) (Abdullah and Ward, 2016; Rahayu and Day, 2017; Toft et al., 2014). The strength of TAM is that it replaced and expanded on many of the TRA measures of attitude with just two technology acceptance measures: perceived ease of use and perceived usefulness (Abdullah and Ward, 2016; Toft et al., 2014). The TAM also has roots in the theory of planned behavior (TPB), which is a modification of the TRA and emphasizes the measures of intention to use technology (Abdullah and Ward, 2016; Toft et al., 2014; Wunnava, 2015; Yeh, 2015). The TAM has been the most robust theory used in studies to explain user acceptance of ICT (Olise et al., 2014). The most appropriate framework for analyzing the business strategies of SME leaders toward making decisions on ICT adoption was TAM, which was appropriate for exploring the effect of different factors, including culture, on the perceived usefulness and perceived ease of use of ICT, particularly among SME leaders in Lagos, Nigeria.

\section{Role of small-to medium-sized enterprises}

SMEs comprise most firms in most economies, contribute significantly to innovation, create jobs and are vital in the development of economies within both developed and developing countries (Mazzarol et al., 2014a; Napitupulu et al., 2018; Rahayu and Day, 2017; Zafar and Mustafa, 2017). The SME sector has played an important role in economic development, poverty alleviation and employment in developing countries (Tarute and Gatautis, 2014). SMEs are a major source of employment, development, and commercialization of innovation and a means to improve global market competitiveness (Mazzarol et al., 2014a; Napitupulu et al., 2018; Rahayu and Day, 2017; Zafar and Mustafa, 2017).

Considering Indonesia, which is a developing country, SMEs account for over 95 per cent of all businesses (Rahayu and Day, 2015)? SMEs account for 99.7 per cent of businesses in the USA and contribute over 70 per cent to its GDP (Elbeltagi et al., 2016; Zafar and Mustafa, 2017). In Africa, SMEs represent 90 per cent of private business and contribute more than 50 per cent of employment and the GDP of most African countries (Elbeltagi et al., 2016; Rahayu and Day, 2017; Tob-Ogu et al., 2018). In Nigeria, SMEs conduct 90 per cent of business in the country and are the primary source of employment in the region (Agwu and Murray, 2015; Gbandi and Amissah, 2014). In economically developed countries, such as the USA, SMEs account for 99 per cent of all firms, employ over 50 per cent of private sector employees, account for 98 per cent of exports, and generate 65 per cent of new private sector jobs; thus, SMEs are the backbone of the USA economy (Thomas, 2014; Elbeltagi et al., 2016). Developing SMEs through entrepreneurship has become a popular strategy for creating jobs, generating revenue, eliminating poverty, and creating an environment for

Impact of
information 
JEFAS 24,47

socioeconomic growth within developing countries (Elbeltagi et al., 2016; Rahayu and Day, 2017; Tob-Ogu et al., 2018; Zafar and Mustafa, 2017).

Various researchers have contended that larger organizations are more beneficial for economic growth because they are more likely to produce innovation than are smaller firms (Harness et al., 2018; Rahayu and Day, 2015), whereas others have argued that SMEs play a more significant role in economic development than their larger counterparts (Rahayu and Day, 2017; Tob-Ogu et al., 2018). Larger organizations have many advantages over small firms, such as deeper levels of specialization, more advanced knowledge in science, an ability to leverage economies of scale, access to cheaper and larger financial resources, and better risk management (Harness et al., 2018; Rahayu and Day, 2017; Tob-Ogu et al., 2018). The advantages that SMEs have over larger organizations are inherent in their size. SMEs and SME leaders have greater flexibility, less bureaucracy, less organizational hierarchy to manage, informal organizational cultures that facilitate better communication, and greater proximity to market; SME leaders are more likely to take on new, innovative ideas (Harness et al., 2018; Rahayu and Day, 2017; Tob-Ogu et al., 2018;). Compared to leaders of larger enterprises, leaders of SMEs are more able to adapt to market conditions because of the size, innovative and flexible nature of SMEs (Napitupulu et al., 2018; Tob-Ogu et al., 2018; Wang et al., 2015).

\section{Factors affecting small-to medium-sized enterprise growth}

SMEs are important in economic development, but numerous factors impede their growth, particularly in developing countries such as Nigeria. These factors include lack of adequate credit; significantly low technological enhancement; inadequate and inefficient infrastructural facilities; shortage of skills; low entrepreneurial skills; and employee turnover that affects performance, productivity, and growth (Gbandi and Amissah, 2014; Tobora, 2014). The national climate for innovation, which involves issues such as government policy, costs of doing business, and quality of communication infrastructure, is a key factor that impacts SME growth (Mazzarol et al., 2014a). Other factors impeding SME development include limited access to appropriate technology, limited access to the global market, government policies, socioeconomic factors, available financial and nonfinancial assistance, weak institutional capacity, weak financial strength, top management leadership skills, managerial characteristics and organizational culture (Jones et al., 2014; Rahayu and Day, 2015, 2017; Tarute and Gatautis, 2014; Tobora, 2014). Thus, to further understand the factors affecting SME growth, it was important to examine the adoption of ICT in developed and developing countries, as discussed next.

\section{Information and communication technology adoption in developing and developed countries}

A review of ICT adoption trends within both developed and developing economies can help to improve the understanding of the challenges of ICT adoption, particularly those faced by SME leaders in developing countries. The adoption and use of ICT represent an enabling mechanism by which organizational leaders improve the efficiency and effectiveness of their business processes, as well as transform existing business models (Jones et al., 2014). Leaders of organizations, including SMEs, must adopt and use ICT to survive in the new business economy (Rahayu and Day, 2017).

The adoption and use of ICT have helped organizations achieve growth by becoming more efficient, effective, innovative and globally competitive (Jones et al., 2014; Rahayu and Day, 2015, 2017; Tarute and Gatautis, 2014). The use of ICT enables SMEs to compete at the same level as their larger counterparts in the global market (Agwu and Murray, 2015). ICT 
adoption within both large and small businesses in developed countries has significantly increased since 2005 (Niebel, 2018; Rahayu and Day, 2017). However, the rate of ICT adoption within SMEs in developing countries has remained relatively low and has contributed to the low rate of economic growth in the region (Jones et al., 2014; Napitupulu et al., 2018; Rahayu and Day, 2017). Compared to large organizations that have noticeably profited from ICT adoption, the rate of ICT adoption within SMEs has remained relatively low (Agwu and Murray, 2015; Harness et al., 2018; Rahayu and Day, 2017; Tob-Ogu et al., 2018).

\section{Advantages of information and communication technology adoption}

Large and small organizations in developed and developing economies can rapidly become formidable competitors while using ICT to create competitive advantage and become market leaders (Mustafa, 2015; Rahayu and Day, 2017). Organizations can use ICT as the means to facilitate strategic planning, future research, and business forecasting for both process efficiency and effectiveness (Agwu and Murray, 2015; Keller and Von der Gracht, 2014). Adopting ICT impacts the flexibility of an organization, where companies whose leaders adopt ICT are more likely to perform better in the market and exhibit product or service differentiation (Tarute and Gatautis, 2014).

Leaders of SMEs have adopted ICT to enhance product and service innovations and create competitive advantage (Napitupulu et al., 2018; Wang et al., 2015; Zafar and Mustafa, 2017). ICT increase the efficiency of an organization and enables effective decision making to explore business opportunities and maximize benefits (Rahayu and Day, 2017). The adoption and use of ICT represents a fundamental avenue for organizations to compete and grow when properly exploited (Rahayu and Day, 2017; Tob-Ogu et al., 2018; Yunis et al., 2017; Zafar and Mustafa, 2017). Adopting new technologies rapidly in SMEs can help to create innovative products and compete globally (Rahayu and Day, 2017; Tob-Ogu et al., 2018; Yunis et al., 2017; Zafar and Mustafa, 2017).

\section{Disadvantages of information and communication technology adoption}

The benefits of ICT depend on how it is used; as a result, ICT could be a disadvantage to some in the same way it is an advantage to others. The use of ICT, particularly with online education provides access to unsupported and erroneous information which makes its difficult and confusing to discern facts (Talebian et al., 2014). Face-to-face interaction has been replaced by online learning and other online social media which fails to address learning preferences of some individuals (Steiner and Mendelovitch, 2017; Talebian et al., 2014). Some studies argue that the use of illustrations through ICT impedes the imagination and stifles creative minds (Steiner and Mendelovitch, 2017).

\section{Factors affecting information and communication technology adoption}

Leaders of SMEs are not fully taking advantage of the potential benefit of ICT compared to large companies, partly because of the limited resources, technology and capabilities of these SMEs (Rahayu and Day, 2015, 2017; Tarute and Gatautis, 2014). These limitations have been significant challenges in many organizations, particularly SMEs, as they are more prone to suffering the effect of these limiting factors because of size and resource limitations (Rahayu and Day, 2017). The shortage of ICT skills and lack of adequate finances experienced in SMEs compared to large organizations have more significant consequences for SMEs than for large firms, thus limiting the ability of SME leaders to create or sustain competitive advantage (Napitupulu et al., 2018; Rahayu and Day, 2017; Tob-Ogu et al., 2018; Zafar and Mustafa, 2017). 
JEFAS

24,47

The barriers to ICT adoption for SMEs include internal and external barriers. The internal barriers include the characteristics of the owner/manager, organizational characteristics, cost of adoption and implementation and return on investment (Tarute and Gatautis, 2014). External barriers include infrastructure, social, cultural, political, legal and regulatory barriers (Agwu and Murray, 2015; Tarute and Gatautis, 2014). Inhibiting factors of ICT adoption among SMEs when compared to large firms included organizational (such as lack of skilled personnel and coherent ICT strategy), financial (such as high investment cost), infrastructural (such as access to power, internet bandwidth and reliable internet connection) and technological (such as the learning curve of evolving technology) factors (Rahayu and Day, 2017).

The low rate of ICT implementation in developing countries is the result of several impeding factors (Rahayu and Day, 2017; Tob-Ogu et al., 2018; Zafar and Mustafa, 2017). Factors that affect the low adoption rate of ICT include low ICT skill level, the cost of implementing ICT, low capital base of SMEs and lack of infrastructure needed to support ICT adoption (Awiagah et al., 2015; Rahayu and Day, 2017; Zafar and Mustafa, 2017). One major factor impeding ICT adoption is the prohibitive cost of ICT implementation, particularly the cost associated with rapidly changing technology (Rahayu and Day, 2017)). Other ICT adoption barriers and constraints identified in developing countries included lack of adequate infrastructure, poor education, financial limitations, political barriers, and sociocultural challenges (Awiagah et al., 2015; Rahayu and Day, 2017; Zafar and Mustafa, 2017). The effect of ICT adoption and the growth of SMEs in developing countries indicated the role of government policies toward the successful implementation of ICT is important to the development of SMEs as well as regional economic growth (Rahayu and Day, 2017; Zafar and Mustafa, 2017). To eliminate any gap between the ICT adoption needs of SMEs and the support government is providing, government leaders must understand precisely what support SMEs need to implement ICT successfully (Agwu and Murray, 2015; Napitupulu et al., 2018; Rahayu and Day, 2017; Tob-Ogu et al., 2018; Zafar and Mustafa, 2017).

One of the attributes of ICT that resulted in the successful implementation of e-commerce by SME leaders in Sub-Saharan Africa, is the ability of SME leaders to see visible benefits resulting from ICT use (Asongu and Le, 2017; Rahayu and Day, 2017; Tob-Ogu et al., 2018). Such visible benefits include the ability for ICT to simplify work routines, promote efficient communication and coordination between various value chain partners, increase productivity, and improve customer service that resulted in increased customer satisfaction (Asongu and Le, 2017; Rahayu and Day, 2017; Tob-Ogu et al., 2018; Zafar and Mustafa, 2017). Many SME leaders saw ICT and e-commerce as avenues to expand their global market reach (Asongu and Le, 2017, Awiagah et al., 2015; Napitupulu et al., 2018; Rahayu and Day, 2017; Tob-Ogu et al., 2018). However, some did not perceive ICT as beneficial in their business (Agwu and Murray, 2015; Rahayu and Day, 2017; Steiner and Mendelovitch, 2017; Talebian et al., 2014), which could explain why many SME leaders use basic ICT features such as word processing, printing, phone calls and faxing; using ICT for advanced functions such as analysis, planning and decision-making was a limitation (Rahayu and Day, 2017). Until SME leaders, particularly in developing countries, address this lack of awareness of ICT benefits, the ICT adoption rate will remain relatively low for SMEs in the region (Jones et al., 2014). Thus, the importance of ICT leadership types was reviewed in existing literature.

\section{Information and communication technology leadership}

In this section, multiple leadership types were explored, particularly how leadership types affect ICT adoption within SMEs. The lived experience of ICT decision makers may explain 
the beliefs and views of these decision-makers toward IT adoption (Awiagah et al., 2015; Hassan et al., 2017; Hickman and Akdere, 2017; Rahayu and Day, 2017; Zafar and Mustafa, 2017). The impact of this lived experience and the correlation between leadership style and ICT adoption may increase the understanding of how SME leaders make decisions to adopt ICT. Leaders of organizations, particularly SMEs, should be aware of the leadership style adopted by their knowledge managers (Tseng, 2017). The dimensions of leadership include transformational, transactional and passive-avoidant (Deprez and Euwema, 2017; Hassan et al., 2017; Hickman and Akdere, 2017; Tseng, 2017). Transformational leadership is a leadership style that transforms employees by altering their ideals, values, morale, and interest to motivate them to perform better than initially expected (Hassan et al., 2017; Hickman and Akdere, 2017; Tseng, 2017; Vermeulen et al., 2014; Yunis et al., 2017). Transactional leadership is a leadership style characterized by a mode of management based on rewards and punishments of subordinates in accordance with the objectives set by the organizational hierarchy (Tseng, 2017; Leduc et al., 2015). Passive-avoidant leadership is a leadership style in which managers avoid decision-making, pay little attention to their subordinates or only pay attention when their subordinates have done something wrong (Hassan et al., 2017; Hickman and Akdere, 2017).

Employee motivation, performance and knowledge management activities increase when knowledge managers or decision-makers adopt transformational and transactional leadership styles (Analoui et al., 2013; Vermeulen et al., 2014). A study on the relationship between leadership style and job satisfaction among employees of SMEs in Nigeria revealed a significant relationship between leadership style and employee job satisfaction that affected productivity (Agwu and Murray, 2015; Hassan et al., 2017; Hickman and Akdere, 2017; Yunis et al., 2017). Transformational leadership style is the most commonly used leadership style within SMEs in Nigeria, and transformational leadership style is an important style for leaders of SMEs to use to achieve the mission, objectives, and developmental goals of the organization (Hassan et al., 2017; Yunis et al., 2017; Zafar and Mustafa, 2017).

Adequate conditions within an organization, including management support and appropriate leadership style, favor successful ICT implementations (Deprez and Euwema, 2017; Rahayu and Day, 2017; Tseng, 2017). The personal quality of a leader is crucial in the approach to decision making within an organization; therefore, understanding leadership style is important in ICT adoption, particularly for SMEs. An association may exist between SME leaders' leadership style and the appointment of ICT coordinators, the development of ICT initiatives and other ICT-related initiatives that foster successful ICT implementation (Agwu and Murray, 2015; Hassan et al., 2017; Hickman and Akdere, 2017; Yunis et al., 2017). Four ICT competencies are important to a firm's development: IT leadership, business system thinking, architectural planning and making the technology work (Yunis et al., 2017). Other reviewed literature emphasized the effect of culture on ICT adoption, as discussed next.

\section{Effect of culture on information and communication technology adoption}

Culture is the values, beliefs, norms and general behavioral patterns of members of a group or category of people that distinguishes them from members of other groups (Matzler et al., 2016). Noneconomic factors that affect ICT adoption decisions include the cultural and psychological aspects of individuals, organizations, societies and countries (Niebel, 2018; Vodanovich and Urquhart, 2017). National culture is a factor that affects ICT adoption, regardless of the economic condition of the country (Deprez and Euwema, 2017; Niebel, 2018;). Culture can impact individuals' decisions to adopt and use technology (Osubor and Chiemeke, 2015). 
JEFAS

24,47

Adoption decisions vary between different societies are based on the attitudes of the people in these communities; as such these social characteristics, may impact the decisions to adopt and use ICT (Rahayu and Day, 2015; Tob-Ogu et al., 2018). Finally, the socioeconomic impact of ICT adoption was an important consideration for this study.

\section{Socioeconomic impact of information and communication technology adoption}

ICT has accelerated economic growth and has contributed to improving the lives of the inhabitants of the world by bringing about new ways of creating livelihoods for people (Napitupulu et al., 2018; Niebel, 2018; Yunis et al., 2017). Empirical evaluation has shown a positive correlation between ICT development and GDP per capita growth (Asongu and Le, 2017; Napitupulu et al., 2018). The social benefits of ICT, particularly for developing countries, include poverty alleviation, job creation, revenue generation and creating an environment for socioeconomic growth (Tarute and Gatautis, 2014; Yunis et al., 2017; Zhang et al., 2014;). SMEs are vital in socioeconomic development, particularly for developing countries (Elbeltagi et al., 2016; Napitupulu et al., 2018; Rahayu and Day, 2017), and leaders of SMEs who adopt ICT provide growth opportunities for the SMEs (Napitupulu et al., 2018; Yunis et al., 2017), which in turn provides socioeconomic benefits within the developing countries.

The adoption and use of ICT helps organizations, particularly government agencies, increase transparency and as such reduces corruption (Charoensukmongkol and Moqbel, 2014). Corruption is the consequence of a problem between public and government agents, where difficulty concerning inadequate supervision results in the abuse of public resources by these government agents $(\mathrm{Li}, 2014)$. ICT provide the means to supervise the activities of government agents, thereby helping to reduce corruption (Li, 2014). With the use of ICT, most government transactions can take place using the internet, thereby eliminating the face-to-face contact between citizens and government agencies and reducing the chances of bribery and corruption (Charoensukmongkol and Moqbel, 2014).

\section{Key findings and analysis}

An extensive analysis of the data collected resulted in the generation of four major themes: ICT role and benefits, ICT adoption factors, role of government and SME success factors. The categorized themes that emerged provided a structure through which to examine the participants' views on the central research question.

\section{Information and communication technology role and benefits}

The analysis of the participants' responses on the role and benefits of ICT produced nine distinct codes: job creation, efficiency productivity and growth, crime and fraud prevention, financial benefits, improved communication, advertisement, competitiveness, globalization and customer relationship (Figure 1). Participants provided different examples of the roles and benefits of ICT in their respective organizations and the broader community.

All participants agreed that ICT adoption leads to more jobs, financial benefits, improved efficiency, increased productivity and growth, which confirmed the findings from multiple studies on the socioeconomic benefits of ICT adoption, particularly in developing countries, which include poverty alleviation, job creation, revenue generation and economic growth (Tarute and Gatautis, 2014; Yunis et al., 2017; Zafar and Mustafa, 2017; Zhang et al., 2014). About 25 per cent of the participants interviewed said that ICT adoption will reduce fraud and help to prevent financial crimes, as the adoption of ICT had resulted in greater accountability and proper audit trails compared to when they used paper-based record keeping in their business process. Researchers in multiple studies agreed with the view of 
some participants that ICT adoption will help in coping with and preventing corruption, fraud and crime (Charoensukmongkol and Moqbel, 2014; Li, 2014; Olaoye and Adebayo, 2017); however, other studies exist that contradict this view. Some researchers had emphasized the increase in cybercrime and other dangers related to Internet-based technologies, particularly in financial transactions in Nigeria, where many experts agree that the infrastructure needed to secure such electronic-based transactions are insufficient or non-existent, with increased vulnerability to fraud (Awiagah et al., 2015; Olaoye and Adebayo, 2017; Schaper, 2015). The increase in ICT use in financial transactions exposes consumers to internet-based fraud, hacking, virus attack, losses and other undue financial charges (Awiagah et al., 2015; Olaoye and Adebayo, 2017).

All participants responded positively to using ICT to gain competitive advantage both in their local market and globally. Company leaders who use ICT-based e-commerce can achieve competitive advantage and cost savings through reduced advertising costs, product differentiation, timely market responses, and improved customer relationships (Awiagah et al., 2015). Leaders of SMEs incrementally use ICT to gain competitive advantage in the global marketplace (Napitupulu et al., 2018; Rahayu and Day, 2017; Tob-Ogu et al., 2018).

\section{Information and communication technology adoption factors}

While analyzing the participants' responses on ICT adoption factors, 11 distinct which were categorized under the ICT adoption factors emerged (Figure 2). The codes were technology type, financial, infrastructure, skills and resources, government, culture, ICT training, trust,

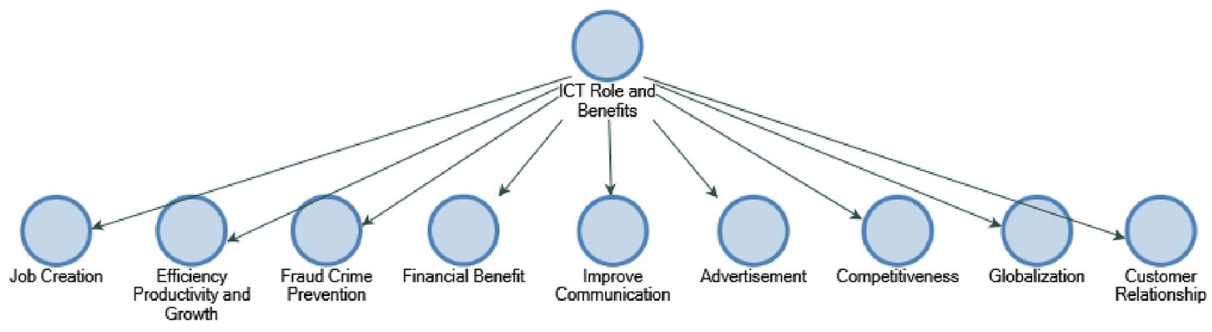

Source: The author
Impact of information
Figure 1.

ICT role and benefits theme and related codes

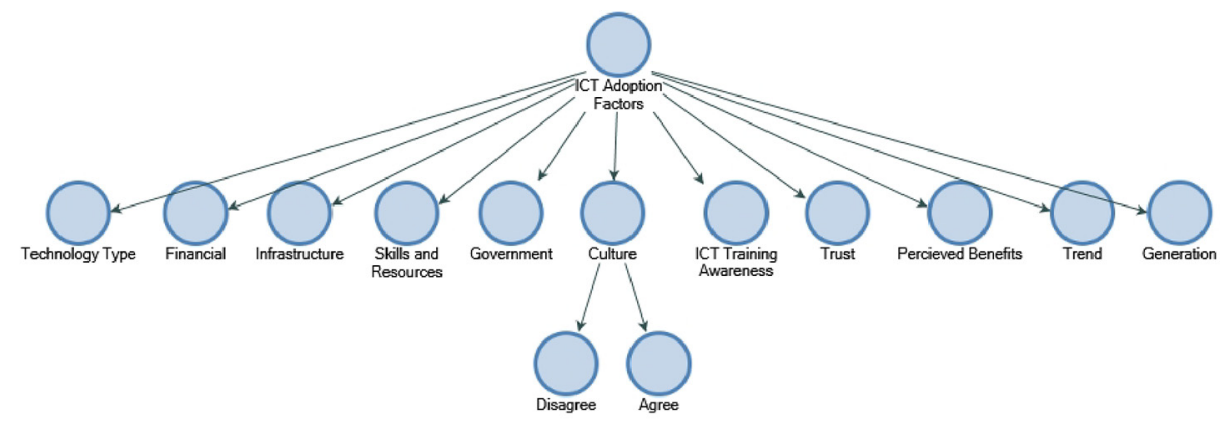

Source: The author

Figure 2. The ICT adoption factors theme and related codes 
JEFAS

24,47

perceived benefits, trend, and generation. Participants identified several factors as influencing their decision to adopt ICT.

All participants agreed that the financial cost of implementing ICT, particularly for SMEs, was a significant factor that was considered before deciding to adopt ICT. According to the participants interviewed, the initial investment in ICT adoption is restrictive to many small businesses that can barely afford the cost of running their daily operation. The costs of purchasing software and computers, hiring skilled ICT personnel, and training existing staff, as well as other costs associated with ICT adoption, are prohibitive for many small businesses (Awiagah et al., 2015; Napitupulu et al., 2018; Rahayu and Day, 2017).

Several participants indicated that the decision to adopt technology depends on the type of technology. These participants agreed that having a company website is necessary for any type of business. Participants also indicated that using online technology, such as social media, online advertising, e-mail and other means to communicate with customers and vendors is vital in the success of any organization. These types of technology are readily available, have a low cost of adoption, are easy to learn, and are affordable to most small businesses. However, some participants noted that many other forms of technology are not readily available, require skilled ICT resources to implement, and are prohibitively expensive for many small businesses. For example, the implementation of some accounting software, customer relationship management software and enterprise resource planning technology is unaffordable for many SMEs.

One of the major factors identified by the study participants was lack of reliable infrastructure to support ICT adoption in Nigeria. The unreliable power supply limited and expensive Internet service, unreliable and expensive telecommunications, bad roads and other infrastructural services not readily available in Nigeria were some of the examples participants cited as influencing their decision to adopt technology. The leaders of many SMEs must provide the infrastructural services they need to succeed, so they have limited resources left to invest in ICT.

All participants agreed that because of the importance of SMEs, particularly toward economic development, government has a responsibility to provide the infrastructure needed to support all types businesses, and to ensure it passes laws and regulations that will allow small businesses to compete favorably with their larger counterparts. Leaders of SMEs lack the competence, market control, and resources available to large firms; as such, the success of SMEs depends on their leaders' ability to be innovative, formulate and implement competitive strategies and respond to changing market conditions under favorable government laws and regulations (Mazzarol et al., 2014b; Rahayu and Day, 2017; Tob-Ogu et al., 2018). Therefore, the policy of the Nigerian government is to develop the economy, help create jobs and eradicate poverty through the development of SMEs (Agwu and Murray, 2015; Tob-Ogu et al., 2018; Zhang et al., 2014).

Culture is a significant code that emerged within the factors that impact ICT adoption in SMEs in Lagos, Nigeria. About half of the participants who discussed the impact of culture on ICT adoption contended that culture had no place or impact on the decision to adopt ICT in their respective organizations. These participants argued that other factors, such as cost of implementation, available ICT skills, unreliable public infrastructure, availability of financial resources and government support for SMEs, were more critical factors that influenced the decision to adopt ICT. The view of participant who contended that culture does not impact ICT adoption contradicted studies that indicated attitude influences individuals' decision to adopt and their aversion to technology. The culture or belief system of a group or society plays a role in the decisions made by individuals of that group (Lapão, 2015; Tob-Ogu et al., 2018). 
Participants, who agreed that culture played a significant role in their decision-making, including the decision to adopt technology, confirmed the findings of several studies on the impact of culture on decision making, particularly in business. Culture or belief plays a role in individual decision making and influences management or business practice, including the decisions made by SME leaders regarding the adoption of ICT for business purposes (Napitupulu et al., 2018; Rahayu and Day, 2017). Culture can be a significant factor in the success of ICT adoption in an organization (Lapão, 2015; Tob-Ogu et al., 2018; Vodanovich and Urquhart, 2017).

\section{Role of government}

The analysis of the participants' responses on the role and benefits of ICT produced six distinct codes: the need for government to adopt ICT, assist with education and training, provide equitable opportunities for businesses, and provide financial assistance, infrastructure and regulations to support SMEs (Figure 3). Several participants responded that government should lead by example by adopting ICT within government agencies. These participants noted that organizations can benefit from government ICT adoption initiatives to facilitate the need for businesses to adopt ICT. According to these participants, if government adopts ICT for transactions such as tax collection, business registration, bill payment and other financial and administrative processes, the leaders of many small businesses will feel encouraged or required to implement ICT when doing business with the government. With the use of ICT, most government transactions can take place using the Internet, thereby helping to reduce the cost of doing business with the government (Charoensukmongkol and Moqbel, 2014).

All participants also identified the lack of a reliable public infrastructure as a significant factor affecting the adoption of ICT, particularly in SMEs. The success of SMEs depends on several factors, including access to reliable infrastructural facilities (Abdullahi et al., 2015). Infrastructure is the physical and organizational structure that guides and supports a society in terms of water, electricity, roads, bridges, telecommunication, sewers and many other factors needed for the effective operation of any society or enterprise (Abdullahi et al., 2015). The government needs to improve existing infrastructural facilities in Nigeria to support the development of SMEs in the country (Abdullahi et al., 2015; Gbandi and Amissah, 2014; Tob-Ogu et al., 2018; Yunis et al., 2017; Zafar and Mustafa, 2017).

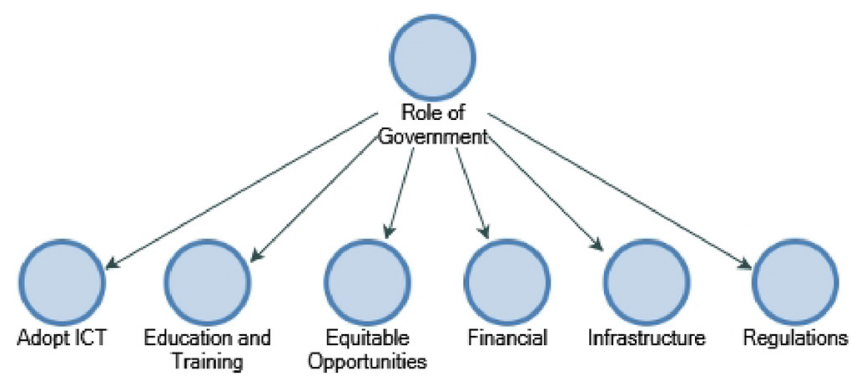

Source: The author Impact of
information

39
Figure 3.

The role of government theme and related codes 
JEFAS

24,47

40

\section{Small-to medium-sized enterprise success factors}

In the data analysis, seven distinct codes were identified, from which the theme SME success factors emerged (Figure 4). All participants interviewed concurred that their decision to implement ICT as part of their business strategy was largely responsible for their business success. Leaders who have adopted and used ICT have helped their organizations achieve growth by becoming more efficient, effective, innovative, and globally competitive (Jones et al., 2014; Napitupulu et al., 2018; Tarute and Gatautis, 2014).

Participants also indicated that having a strong product or service brand is crucial to the success of any business. These participants noted that organizations must deliver its products and services at a time, quality, quantity and cost anticipated by the market to be successful. Consumers are more likely to purchase products or services with positive brand images because this has the effect of lowering consumers' perceived risk and increasing their perceived value (Yeh, 2015). E-commerce and ICT have changed the way organizations conduct business and forced organizations to provide innovative products and services more effectively and efficiently to meet consumers' needs (Mustafa, 2015; Niebel, 2018; Rahayu and Day, 2017; Vodanovich and Urquhart, 2017).

Customer relation was another factor identified by some participants as key to the success of their business. According to these participants, the adoption of ICT and having innovative products or services, without having good customer relationships, will be insufficient to make any business a success. The relationship between customers and organizations is important because customers buy products or services from these organizations (Hassan et al., 2017; Rahayu and Day, 2017; Napitupulu et al., 2018). Some visible benefits of ICT adoption include the ability to simplify work routines, promote efficient communication and coordination between various value chain partners, increase productivity, and improve customer service that results in increased customer satisfaction (Napitupulu et al., 2018; Rahayu and Day, 2017; Tarute and Gatautis, 2014; Zafar and Mustafa, 2017).

All participants indicated that the availability of financial resources to SMEs is crucial to their business success. Larger organizations have many advantages over small firms, including the ability to leverage economies of scale, access to cheaper and larger financial resources, and the ability to mitigate business and financial risk (Agwu and Murray, 2015; Harness et al., 2018; Rahayu and Day, 2017; Tob-Ogu et al., 2018). Leaders of SMEs in Nigeria face several challenges such as inadequate access to finance, improper financial and management practices, inadequate entrepreneurial skills and inadequate ICT adoption in business management (Gbandi and Amissah, 2014; Tob-Ogu et al., 2018; Yunis et al., 2017; Zafar and Mustafa, 2017). Some participants contended that leaders of large organizations can find additional capital easier to fill the gap where government has failed. Other participants noted that setting clear strategic business goals, choosing the right business

Figure 4. The SME success factors theme and related codes

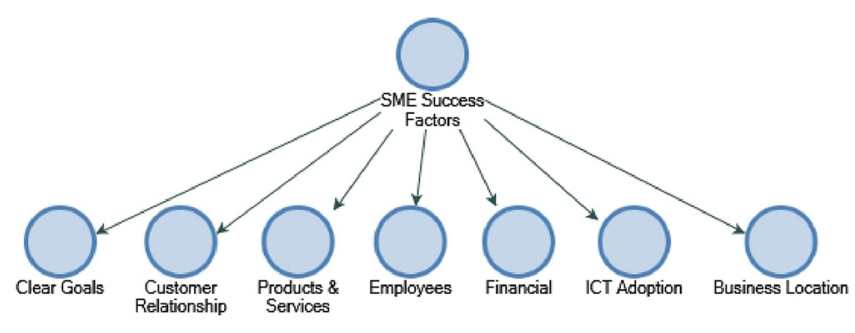

Source: The author 
location, access to skilled resources and rewarding employees adequately were key to their success.

\section{Discussion of findings}

The intent of this study was to explore the factors that impact SME leaders' adoption of ICT as a business strategy to achieve competitive advantage in the global market. The SME sector has played a significant role in economic development, poverty alleviation, and job creation in both developed and developing countries (Rahayu and Day, 2017; Mazzarol et al., 2014a, 2014b; Napitupulu et al., 2018; Tarute and Gatautis, 2014; Zafar and Mustafa, 2017). However, SME leaders face multiple challenges in achieving profitability, growth and competitiveness locally and globally, particularly in Lagos, Nigeria. The findings of this study are valuable to leaders of SMEs and government agencies, as well as other community partners looking to explore and understand the benefits and challenges of ICT adoption, particularly for SMEs in Lagos, Nigeria. The findings from this study fit into four major themes: SME role and benefits, ICT adoption factors, role of government and SME success factors. Each theme contributes to the professional practice within SMEs, particularly in Lagos, Nigeria.

\section{Role and benefits of information and communication technology to small-to medium-sized enterprises}

The study findings categorized under the SME role and benefits theme has significant implications on SMEs leaders' attitude toward ICT adoption and the ways they perceive the usefulness of ICT, particularly the benefits that ICT would bring to their respective organizations. Organizational leaders adopt and use ICT to achieve significant growth by becoming more efficient, effective, innovative and globally competitive (Jones et al., 2014; Napitupulu et al., 2018; Tarute and Gatautis, 2014). Most significantly, SME leaders use ICT to compete at the same level as their larger counterparts in the global market (Agwu and Murray, 2015). The findings from this study may help leaders of SMEs make informed decisions on ICT adoption and the impact toward achieving their strategic objectives of innovation, growth, profitability and competitiveness.

\section{Factors that impact information and communication technology adoption in small-to medium-sized enterprises}

From this study findings, several factors affect ICT adoption by SME leaders in Lagos, Nigeria, including the type of technology, availability of financial resources, reliable infrastructure, and availability of ICT skilled resources, role of government, culture and attitude toward technology, perceived benefits and generational differences. The findings from this study aligned with other studies on the impact of ICT adoption in SMEs in developing countries, where financial limitations, unreliable infrastructure, skills shortage, ICT knowledge gap, and insufficient government support emerged as factors that inhibit ICT adoption, with SMEs affected more than larger organizations (Elbeltagi et al., 2016; Napitupulu et al., 2018; Rahayu and Day, 2017;Tarute and Gatautis, 2014). SME leaders and government agencies need to understand the implications of these factors, particularly to SMEs resulting in better decision making.

\section{The role of government}

With a clear understanding of the role, benefits and challenges faced by SME leaders regarding ICT adoption, the role of government in addressing many of these challenges in Lagos, Nigeria, becomes clear. The effect of ICT adoption and the growth of SMEs in 
JEFAS

24,47

developing countries indicate the role of government policies toward the successful implementation of ICT is important for developing SMEs as well as for regional economic growth (Rahayu and Day, 2017; Napitupulu et al., 2018; Vodanovich and Urquhart, 2017). Government has a responsibility to provide infrastructural facilities, financial support, and regulations to promote and support the growth of business, particularly SMEs, in society (Mazzarol et al., 2014a, 2014b; Rahayu and Day, 2017; Zafar and Mustafa, 2017). The Nigerian government can help facilitate the development of SMEs by providing financial aid, technical training centers, reliable infrastructure and regulations that support ICT adoption. Decision-makers within SMEs and government policy makers may use the findings of this study to plan for successful ICT adoption.

\section{Implications of small-to medium-sized enterprise success factors}

In this study, several factors emerged that have contributed to the success of SMEs in Lagos, Nigeria, including the adoption and use of ICT, innovative products and services brand, good customer relationships, access to financial resources, setting clear strategic business goals and having the right employees. Leaders who have adopted and used ICT have helped businesses become efficient, effective, innovative and globally competitive (Jones et al., 2014; Napitupulu et al., 2018; Tarute and Gatautis, 2014). The use of ICT has transformed business processes, and leaders have developed innovative products and services more effectively and efficiently to meet consumers' needs (Mustafa, 2015; Napitupulu et al., 2018; Rahayu and Day, 2017; Zafar and Mustafa, 2017). However, ICT adoption by SME leaders becomes a challenge without access to financial resources to offset the cost of rapidly changing technology (Rahayu and Day, 2017; Napitupulu et al., 2018; Rahayu and Day, 2017; Tob-Ogu et al., 2018; Zafar and Mustafa, 2017). Setting clear strategic business goals with the right workforce contributed to the success of the SMEs whose leaders participated in this study; thus, leaders of SMEs in Lagos, Nigeria, can use the findings in this study to address some of the challenges they face with growth, profitability and global competitiveness.

\section{Implications for social change}

Based on the literature reviewed and the findings from this study, SMEs are an integral part of innovation and growth in a dynamic economy; thus, SMEs play a critical role in job creation, poverty alleviation, and socioeconomic development in both developed and developing countries (Mazzarol et al., 2014a, 2014b; Napitupulu et al., 2018; Tarute and Gatautis, 2014; Tob-Ogu et al., 2018). Adopting ICT will result in the success and growth of SMEs, which positively affects social change by creating jobs, alleviating poverty and developing the local economy (Agwu and Murray, 2015; Jones et al., 2014; Napitupulu et al., 2018). Findings from this study may facilitate an increase in ICT adoption by leaders of SMEs in Nigeria, which in turn would have positive social impact.

\section{Recommendations for action}

Two critical roles in the successful adoption and use of ICT were identified in this study: the role of SME leaders and the role of government. Leaders of SMEs must take critical steps to support the adoption and use of ICT in their organizations by identifying the appropriate types of technology that meet organizations' strategic objectives, identifying the cost and source of financing for ICT projects, hiring skilled ICT resources or train existing employees on using and supporting ICT projects, determining the appropriate leadership style for ICT adoption and organizational success and providing ongoing training and support for new ICT projects as business needs evolve. Government leaders need to put laws and regulations in place that support SMEs, provide tax incentives for ICT adoption by SMEs, offer financial incentives and 
loan guarantees to SMEs toward ICT adoption, support ICT training centers and take appropriate steps to promote and adopt ICT use within all government agencies. Most important, government leaders need to ensure leaders of SMEs have access to reliable infrastructure, including regular electricity, reliable telecommunication, good roads and other infrastructural facilities that would help reduce the cost of doing business, particularly in Nigeria.

\section{Conclusions}

The purpose of this study was to explore how SME leaders in Lagos, Nigeria, use ICT adoption as a business strategy to increase profitability and compete globally. The aim of this study was to advance knowledge on the factors that affect ICT adoption in developing countries, particularly within SMEs in Nigeria. The focus of this study was on the factors that affect ICT adoption by SME leaders as a business strategy to increase profitability and compete globally, particularly within SMEs in Lagos, Nigeria. Two critical roles in the successful adoption and use of ICT were identified: the role of SME leaders and the role of government. Because of the increasingly important role SMEs play in job creation, poverty alleviation and the socioeconomic development of any region (Abdullahi et al., 2015; Rahayu and Day, 2017; Mazzarol et al., 2014a, 2014b; Tarute and Gatautis, 2014; Tob-Ogu et al., 2018;), government leaders have a significant role to play in ensuring SMEs have the resources needed to succeed. Leaders of SMEs also have a critical role to play in the successful adoption of ICT in their organizations.

\section{References}

Abdullah, F. and Ward, R. (2016), "Developing a general extended technology acceptance model for elearning (GETAMEL) by analysing commonly used external factors", Computers in Human Behavior, Vol. 56, pp. 238-256, doi: 10.1016/j.chb.2015.11.036.

Abdullahi, M., Ghazali, P., Awang, Z., Tahir, I. and Ali, N. (2015), "The effect of finance, infrastructure and training on the performance of small and medium scale enterprises (SMEs) in Nigeria”, International Journal of Business and Technopreneurship, Vol. 5 No. 3, pp. 421-452, available at: https://ijbt.unimap.edu.my/index.php?option=com_content\&view= article\&id=78\&Itemid=89 (accessed 24 June 2018).

Agwu, E.M. and Murray, P.J. (2015), "Empirical study of barriers to electronic commerce uptake by SMEs in developing economies", International Journal of Innovation in the Digital Economy, Vol. 6 No. 2, pp. 1-19, doi: 10.4018/ijide.2015040101.

Analoui, B.D., Doloriert, C.H. and Sambrook, S. (2013), "Leadership and knowledge management in UK ICT organisations", Journal of Management Development, Vol. 32 No. 1, pp. 4-17, doi: 10.1108/ 02621711311286892.

Asongu, S.A. and Le, S. (2017), "Technological forecasting and social change enhancing ICT for inclusive human development in Sub-Saharan Africa", Technological Forecasting and Social Change, Vol. 118 No. 5, pp. 44-54, doi: 10.1016/j.techfore.2017.01.026.

Awiagah, R., Kang, J. and Lim, J.I. (2015), "Factors affecting e-commerce adoption among SMEs in Ghana", Information Development, Vol. 32 No. 4, pp. 815-836, doi: 10.1177/0266666915571427.

Charoensukmongkol, P. and Moqbel, M. (2014), "Does investment in ICT curb or create more corruption? A cross-country analysis", Public Organization Review, Vol. 14 No. 1, pp. 51-63, doi:10.1007/s11115-012-0205-8.

Deprez, J. and Euwema, M. (2017), "You can't always get what you want? Leadership expectations of intrapreneurs”, Journal of Managerial Psychology, Vol. 32 No. 6, pp. 430-444, doi: 10.1108/JMP-042016-0107.

Elbeltagi, I., Hamad, H., Moizer, J. and Abou-Shouk, M.A. (2016), "Levels of business to business e-commerce adoption and competitive advantage in small and medium-sized enterprises: a
Impact of information 


\section{JEFAS 24,47}

comparison study between Egypt and the United States", Journal of Global Information Technology Management, Vol. 19 No. 1, pp. 6-25, doi: 10.1080/1097198X.2016.1134169.

Gbandi, E.C. and Amissah, G. (2014), "Financing options for small and medium enterprises (SMEs) in Nigeria”, European Scientific Journal, Vol. 10 No. 1, pp. 327-340, available at: http://eujournal.org/ index.php/esj (accessed 11 July 2018).

Harness, D., Ranaweera, C., Karjaluoto, H. and Jayawardhena, C. (2018), "The role of negative and positive forms of power in supporting CSR alignment and commitment between large firms and SMEs. Industrial marketing management”, Vol. 69 No. 2 (February), pp. 0-1, doi: 10.1016/j. indmarman.2018.03.006.

Hassan, A.M., Mike, I. and Guyo, W. (2017), "Effect of integrated service approach on service delivery at huduma centres in the public service of Kenya", European Journal of Business and Social Sciences, Vol. 6 No. 3, pp. 1-12, available at: www.ejbss.com/recent.aspx-/ (accessed 15 July 2018).

Hickman, L. and Akdere, M. (2017), "Effective leadership development in information technology: Building transformational and emergent leaders", Industrial and Commercial Training, Vol. 50 No. 1, pp. 1-9, doi: 10.1108/ICT-06-2017-0039.

International Telecommunication Union (2014), "Key ICT indicators, 2005-2010", available at: www.itu. int/en/ITU-D/Statistics/Pages/stat/defaultaspx (accessed 22 March 2018).

Jones, P., Simmons, G., Packham, G., Beynon-Davies, P. and Pickernell, D. (2014), "An exploration of the attitudes and strategic responses of sole-proprietor micro-enterprises in adopting ICT", International Small Business Journal, Vol. 32 No. 3, pp. 285-306, doi: 10.1177/0266242612461802.

Keller, J. and Von der Gracht, H.A. (2014), "The influence of information and communication technology (ICT) on future foresight processes: results from a delphi survey", Technological Forecasting and Social Change, Vol. 85, pp. 81-92, doi: 10.1016/j.techfore.2013.07.010.

Lapão, L.V. (2015), “The challenge of benchmarking health systems: is ICT innovation capacity more systemic than organizational dependent?", Israel Journal of Health Policy Research, Vol. 4 No. 1, pp. 10-13, doi: 10.1186/s13584-015-0036-5.

Leduc, S., Guilbert, L. and Vallery, G. (2015), "Impact of ICTs on leadership practices: representations and actions", Leadership and Organization Development Journal, Vol. 36 No. 4, pp. 380-395, doi: 10.1108/LODJ-07-2013-0090.

Li, S. (2014), "The impact of information and communication technology on relation-based governance systems", Information Technology for Development, Vol. 11 No. 2, pp. 105-122, doi: 10.1002/itdj.20010.

Matzler, K., Strobl, A., Stokburger-Sauer, N., Bobovnicky, A. and Bauer, F. (2016), "Brand personality and culture: the role of cultural differences on the impact of Brand personality perceptions on tourists' visit intentions", Tourism Management, Vol. 52, pp. 507-520, doi: 10.1016/j. tourman.2015.07.017.

Mazzarol, T., Clark, D.N. and Reboud, S. (2014a), "Strategy in action: case studies of strategy, planning and innovation in Australian SMEs", Small Enterprise Research, Vol. 21 No. 1, pp. 54-71, doi: 10.1080/13215906.2014.11082076.

Mazzarol, T., Clark, D., Reboud, S., Gough, N. and Olson, P. (2014b), "Perceptions of innovation climate and the influence of others: a multi-country study of SMEs", International Journal of Innovation Management, Vol. 18 No. 1, pp. 1-24, doi: 10.1142/S1363919614500091.

Mustafa, H.H. (2015), "The role of ICT management to achieve organizational innovation”, International Journal of Organizational Innovation, Vol. 7 No. 4, pp. 48-56, available at: www.ijoi-online.org/ (accessed 27 July 2018).

Napitupulu, D., Syafrullah, M., Rahim, R., Abdullah, D. and Setiawan, M.I. (2018), "Analysis of user readiness toward ICT usage at small medium enterprise in South tangerang", Journal of Physics: Conference Series, Vol. 1007 No. 1, doi: 10.1088/1742-6596/1007/1/012042.

Niebel, T. (2018), "ICT and economic growth - Comparing developing, emerging and developed countries”, World Development, Vol. 104 No. C, pp. 197-211, doi: 10.1016/j.worlddev.2017.11.024. 
Olaoye, F.O. and Adebayo, I.A. (2017), "Empirical evaluation of government cashless policy and accountants workload in selected higher institutions in Ekiti state, Nigeria abstract", International Journal of Innovative Research and Development, Vol. 6 No. 10, pp. 1-6, available at: www.ijird.com/ (accessed 21 April 2018).

Olise, M.C., Anigbogu, T.U. and Okoli, M.I. (2014), "Determinants of ICT adoption for improved SME's performance in Anambra", American International Journal of Contemporary Research, Vol. 4 No. 7, pp. 163-176, available at: www.aijcrnet.com/ (accessed 25 July 2018).

Osubor, V.O. and Chiemeke, S.C. (2015), "The impacts of information culture on e-learning innovation adoption in learning institutions in Nigeria", African Journal of Computing and ICT, Vol. 8 No. 1, pp. 17-26, available at: www.ajocict.net (accessed 06 July 2018).

Rahayu, R. and Day, J. (2015), "Determinant factors of e-commerce adoption by SMEs in developing country: evidence from Indonesia", Procedia - Social and Behavioral Sciences, Vol. 195, pp. 142-150, doi: 10.1016/j.sbspro.2015.06.423.

Rahayu, R. and Day, J. (2017), "E-commerce adoption by SMEs in developing countries: evidence from Indonesia”, Eurasian Business Review, Vol. 7 No. 1, pp. 25-41, doi: 10.1007/s40821-016-0044-6.

Schaper, M.T. (2015), "Competing in the online marketplace: contemporary issues for SMEs and their regulators", Small Enterprise Research, Vol. 22 No. 1, pp. 69-78, doi: 10.1080/13215906.2015.1017075.

Steiner, D. and Mendelovitch, M. (2017), "I'm the same teacher: the attitudes of science and computer literacy teachers regarding integrating ICT in instruction to advance meaningful learning", Eurasia Journal of Mathematics, Science and Technology Education, Vol. 13 No. 5, pp. 1259-1282, doi: 10.12973/eurasia.2017.00670a.

Talebian, S., Mohammadi, H.M. and Rezvanfar, A. (2014), "Information and communication technology (ICT) in higher education: advantages, disadvantages, conveniences and limitations of applying e-learning to agricultural students in Iran", Procedia - Social and Behavioral Sciences, Vol. 152, pp. 300-305, doi: 10.1016/j.sbspro.2014.09.199.

Tarute, A. and Gatautis, R. (2014), "ICT impact on SMEs performance”, Procedia - Social and Behavioral Sciences, Vol. 110, pp. 1218-1225, doi: 10.1016/j.sbspro.2013.12.968.

Thomas, N.K. (2014), "The role of SMEs in employment creation and economic growth in selected countries", International Journal of Education and Research, Vol. 2 No. 12, pp. 461-472, available at: www.ijern.com/ (accessed 28 July 2018).

Tob-Ogu, A., Kumar, N. and Cullen, J. (2018), "ICT adoption in road freight transport in Nigeria - A case study of the petroleum downstream sector", Technological Forecasting and Social Change, Vol. 131, pp. 240-252, doi: 10.1016/j.techfore.2017.09.021.

Tobora, O.O. (2014), "Challenges faced by entrepreneurs and the performance of small and medium scale enterprises (SMEs) in Nigeria: an intellectual Capital issue”, International Letters of Social and Humanistic Sciences, Vol. 42, pp. 32-40, doi: 10.18052/www.scipress. com/ILSHS.42.32.

Toft, M.B., Schuitema, G. and Thøgersen, J. (2014), "Responsible technology acceptance: model development and application to consumer acceptance of smart grid technology", Applied Energy, Vol. 134, pp. 392-400, doi: 10.1016/j.apenergy.2014.08.048.

Tseng, S.M. (2017), "Investigating the moderating effects of organizational culture and leadership style on IT-adoption and knowledge-sharing intention", Journal of Enterprise Information Management, Vol. 30 No. 4, pp. 583-604, doi: 10.1108/JEIM-04-2016-0081.

Vermeulen, M., Van Acker, F., Kreijns, K. and van Buuren, H. (2014), "Does transformational leadership encourage teachers' use of digital learning materials?", Educational Management Administration and Leadership, Vol. 43 No. 6, pp. 1-20, doi: 10.1177/1741143214535749.

Vodanovich, S. and Urquhart, C. (2017), "ICTs and the computerised hijab: women's experiences of ICT in the UAE", Electronic Journal of Information Systems in Developing Countries, Vol. 82 No. 1, pp. 1-17, doi: 10.1002/j.1681-4835.2017.tb00608.x. 
JEFAS

24,47

Wang, K.Y., Hermens, A., Huang, K.P. and Chelliah, J. (2015), "Entrepreneurial orientation and organizational learning on SMEs' innovation”, International Journal of Organizational Innovation, Vol. 7 No. 4, pp. 71-81, available at: www.ijoi-online.org/ (accessed 29 July 2018).

Wunnava, S. (2015), "Mobile commerce usage: application of theory of reasoned action (TRA) and technology acceptance model (TAM)", World Journal of Social Sciences, Vol. 5 No. 2, pp. 41-50, available at: www.wbiaus.org/wjss_new.html (accessed 24 July 2018).

Yeh, H. (2015), "Effects of ICT's innovative applications on Brand image and customer's purchase intention", International Journal of Organizational Innovation, Vol. 7 No. 4, pp. 31-48, available at: www.ijoi-online.org/ (accessed 7 May 2018).

Yunis, M., El-Kassar, A. and Tarhini, A. (2017), "Impact of ICT-based innovations on organizational performance: the role of corporate entrepreneurship", Journal of Enterprise Information Management, Vol. 30 No. 1, pp. 122-141, doi: 10.1108/JEIM-01-2016-0040.

Zafar, A. and Mustafa, S. (2017), "SMEs and its role in economic and socio-economic development of Pakistan", International Journal of Academic Research in Accounting, Finance and Management Sciences, Vol. 7 No. 4, pp. 195-205, doi: 10.6007/IJARAFMS/v7-i4/3484.

Zhang, X., Ma, X. and Wang, Y. (2014), "How can emerging market small and medium-sized enterprises maximise internationalisation benefits? The moderating effect of organisational flexibility", International Small Business Journal, Vol. 32 No. 6, pp. 667-692, doi: 10.1177/0266242613503356.

\section{About the authors}

Dr Kessington Okundaye holds a Doctorate of Business Administration (DBA) in Information Systems Management from Walden University, School of Management and Technology. He is a result-oriented Information Technology (IT) Executive and Business Solutions Architect with extensive industry experience developing and executing operational strategies to promote organizational growth and optimizing the utilization of emerging technology in meeting these goals. He had previously worked in various IT leadership positions for organizations in the financial and technology sectors, and is currently the Co-founder and Chief Executive Officer of Rekun Technologies, an IT security and business solutions consulting firm.

Dr Susan K. Fan, DM, in Organizational Leadership. She has worked as a management professional in various leadership positions for several Fortune 100 companies. She is currently working as Contributing Faculty and Doctoral Mentor with the DBA Program at Walden University and as an Adjunct Faculty with Purdue University Global's MBA program. Her research interests include but are not limited to leader-follower relationships, organizational leadership, change management, leadership in sustainable organizations. She is also enrolled in a Counseling Psychology MFT Licensing Program to equip herself to work with the local communities towards preventive mental health care initiatives.

Dr Rocky J. Dwyer, PhD, FCPA, FCMA is a Contributing Faculty Professor at Walden University College Management and Technology. Dr Dwyer is an award-winning writer, editor and educator, who has consulted and undertaken research for private, not-for profit and public sector organizations to examine and validate corporate social responsibility, poverty-reduction initiatives, strategic organizational capacity, and performance management. His research has been presented and published for conferences and symposiums in Canada, the USA, South America, Germany, the Russian Federation and the People's Republic of China. Rocky J. Dwyer is the corresponding author and can be contacted at: rocky.dwyer@mail.waldenu.edu

For instructions on how to order reprints of this article, please visit our website:

www.emeraldgrouppublishing.com/licensing/reprints.htm

Or contact us for further details: permissions@emeraldinsight.com 